\title{
NITROUS OXIDE AND CARBON DIOXIDE EMISSIONS FROM AGRICULTURAL SOIL AMENDED WITH DIFFERENT TYPES OF BIOCHAR AT THREE TEMPERATURES
}

\author{
Ngoc Tuong Van HOANG ${ }^{1}$ and Morihiro MAEDA ${ }^{2 *}$ \\ ${ }^{1}$ Graduate School of Environmental and Life Science, Okayama University \\ (3-1-1 Tsushima-Naka, Kita-Ku, Okayama 700-8530, Japan) \\ E-mail: tuongvan1508@gmail.com \\ ${ }^{2}$ Professor, Graduate School of Environmental and Life Science, Okayama University \\ (3-1-1 Tsushima-Naka, Kita-Ku, Okayama 700-8530, Japan) \\ ${ }^{*}$ Corresponding author E-mail: mun@cc.okayama-u.ac.jp
}

\begin{abstract}
A laboratory experimental study was conducted to investigate the effects of different coffee waste biochar materials at three temperatures on nitrous oxide $\left(\mathrm{N}_{2} \mathrm{O}\right)$ and carbon dioxide $\left(\mathrm{CO}_{2}\right)$ emissions from agricultural soil in Central Vietnam. Soil amended with 2\% normal biochar, $2 \%$ functional biochar (with a high $\mathrm{NO}_{3}-\mathrm{N}$ adsorption capacity of $20 \mathrm{~g} \mathrm{~N} \mathrm{~kg}^{-1}$ ) or no addition was adjusted at $60 \%$ water holding capacity, conditioned with $100 \mathrm{mg} \mathrm{N}-\mathrm{NO}_{3} \mathrm{~kg}^{-1}$ dried-soil and aerobically incubated at $25^{\circ} \mathrm{C}, 30^{\circ} \mathrm{C}$ or $35^{\circ} \mathrm{C}$ for 21 days. $\mathrm{N}_{2} \mathrm{O}$ and $\mathrm{CO}_{2}$ emissions were measured on days 1, 3, 5, 7, 14 and 21. Results showed that the addition of normal biochar caused more $\mathrm{CO}_{2}$ emission but less $\mathrm{N}_{2} \mathrm{O}$ emission compared to the functional biochar application. At $25^{\circ} \mathrm{C}$, biochar amendment had a neutral or positive effect on $\mathrm{N}_{2} \mathrm{O}$ and $\mathrm{CO}_{2}$ emissions. At $35^{\circ} \mathrm{C}$, biochar amendment reduced $\mathrm{N}_{2} \mathrm{O}$ and $\mathrm{CO}_{2}$ emissions compared to the control. However, there was little difference in $\mathrm{N}_{2} \mathrm{O}$ and $\mathrm{CO}_{2}$ emissions among biochar treatments. In addition, with increasing temperature, a positive correlation between temperature and $\mathrm{N}_{2} \mathrm{O}$ and $\mathrm{CO}_{2}$ emissions with the non-biochar amendment and a negative correlation between temperature and $\mathrm{N}_{2} \mathrm{O}$ with the biochar treatments were observed. This is because temperature probably affects the rate of microbial processes mediating respiration and denitrification and the soil-biochar mixture's mobilization of $\mathrm{N}$ availability.
\end{abstract}

Key Words: carbon dioxide, functional biochar, nitrous oxide, normal biochar, temperature.

\section{INTRODUCTION}

Nitrous oxide is a long-lived gas in the atmosphere with global warming potential 298 times that of $\mathrm{CO}_{2}$ for a time horizon of 100 years ${ }^{1)}$. Agriculture is a source of $\mathrm{N}_{2} \mathrm{O}, \mathrm{CO}_{2}$ and $\mathrm{CH}_{4}$, and accounted for $10-12 \% \mathrm{CO}_{2}$-equivalent to total global greenhouse gas (GHG) emissions ${ }^{2}$. Intensive vegetable cropping systems often receive excess nitrogen $(\mathrm{N})$ application and result in greater $\mathrm{N}_{2} \mathrm{O}$ emissions and water quality deterioration ${ }^{3445)}$.

Biochar is considered a useful soil amendment to improve soil properties, increase carbon sequestration and reduce GHG emissions from soil ${ }^{6}$. Amendment of soil with biochar reduced $\mathrm{N}_{2} \mathrm{O}$ emissions by $54 \%{ }^{7)}$ and $76 \%^{8}$. However, there have been studies reporting no difference or even an increase in $\mathrm{N}_{2} \mathrm{O}$ emissions after biochar application ${ }^{899) 10) 11)}$. Spokas et al. (2009) reported that two chars (Biosource $^{\mathrm{TM}}$ and Macadamia shell) increased the observed $\mathrm{N}_{2} \mathrm{O}$ production by $295 \%$ and $1627 \%$, respectively. On the other hand, the addition of 16 different biochars to agricultural soil $(10 \% \mathrm{w} / \mathrm{w})$ resulted in different responses in $\mathrm{CO}_{2}$ emission: five chars increased it, two chars reduced it and nine caused no significant change ${ }^{9}$.

The major factors controlling $\mathrm{N}_{2} \mathrm{O}$ emission from agricultural soil are soil $\mathrm{N}$ availability, dissolved organic $\mathrm{C}$ (DOC), temperature, moisture and $\mathrm{pH}$. Total cumulative $\mathrm{N}_{2} \mathrm{O}$ emission was enhanced by $\mathrm{N}$ application ${ }^{12)}$ and high temperature ${ }^{13) 14}$. Increasing temperature could enhance $\mathrm{N}_{2} \mathrm{O}$ emission from soils by enhancing nitrification and denitrification rates. The optimal 
temperature for the nitrification process was $32.5^{\circ} \mathrm{C}$, whereas that for denitrification was $45^{\circ} \mathrm{C}^{15)}$. Soil respiration is also stimulated by a temperature increase. Panosso et al. (2011) showed that $\mathrm{CO}_{2}$ emission in tropical areas was often higher than in temperate regions. Because most of the studies were conducted at $0-25^{\circ} \mathrm{C}$, the effects of high temperature on $\mathrm{CO}_{2}{ }^{14) 16)}$ and $\mathrm{N}_{2} \mathrm{O}^{14)}$ have not been well documented. Little is known about high temperature effects on $\mathrm{N}_{2} \mathrm{O}$ and $\mathrm{CO}_{2}$ emissions from biocharamended soil in tropical vegetable fields. In this study, we selected a field used for intensive vegetable cultivation in central Vietnam where the groundwater was contaminated with $\mathrm{NO}_{3}-\mathrm{N}$, probably due to excess use of $\mathrm{N}$ fertilizer. Normal biochar and a biochar with high $\mathrm{NO}_{3}-\mathrm{N}$ adsorption capacity, a functional biochar produced from coffee waste, were used as soil amendments to evaluate the ability to mitigate $\mathrm{N}_{2} \mathrm{O}$ emissions from the Vietnamese agricultural soil. The functional biochar

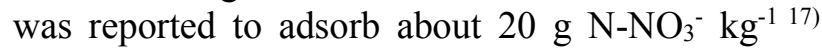
and we hypothesized that functional biochar produces less $\mathrm{N}_{2} \mathrm{O}$ when added to soil compared to the normal biochar due to its adsorption ability.

The objectives of this study were to 1) determine the effects of different coffee waste biochar materials on $\mathrm{N}_{2} \mathrm{O}$ and $\mathrm{CO}_{2}$ emissions and 2) investigate the response of $\mathrm{N}_{2} \mathrm{O}$ and $\mathrm{CO}_{2}$ emissions from agricultural soil to different temperatures.

\section{MATERIALS AND METHODS}

\section{Soil characterization}

Soil was collected from 0 to $10 \mathrm{~cm}$ depth in a vegetable field in Phu Mau Commune, Phu Vang district, Thua Thien Hue province, Vietnam $\left(16^{\circ} 29^{\prime} 53 \mathrm{~N}, 107^{\circ} 34^{\prime} 47 \mathrm{E}\right)$. This soil is a sandy loam (Fluvisol) with $71 \%$ sand, $18 \%$ silt and $11 \%$ clay. The study field had been planted with mustard (Brassica juncea) and amaranth (Amaranthus mangostanus). The air-dried soil sample was passed through a 2-mm sieve and characterized as follows: $\mathrm{pH}(1: 5), 7.8 ; \mathrm{EC}(1: 5), 0.116 \mathrm{dS} \mathrm{m}^{-1} ; \mathrm{NO}_{3}-\mathrm{N}, 41 \mathrm{mg}$ $\mathrm{N} \mathrm{kg}^{-1} ; \mathrm{NH}_{4}-\mathrm{N}, 0.3 \mathrm{mg} \mathrm{N} \mathrm{kg}^{-1} ; \mathrm{TN}, 0.7 \mathrm{~g} \mathrm{~kg}^{-1}$; TC, 7.5 $\mathrm{g} \mathrm{kg}^{-1} ; \mathrm{C} / \mathrm{N}$ ratio, 11 and cation exchange capacity (CEC), $6.63 \mathrm{cmol}_{\mathrm{c}} \mathrm{kg}^{-1}$.

\section{Coffee waste biochar}

Normal (NB) and functional coffee waste biochar materials (FB) were incinerated at $600^{\circ} \mathrm{C}$ for $1 \mathrm{~h}$. The raw material of the biochar (waste coffee grounds) was collected from a coffee canning factory in Okayama, Japan. The functional biochar was manufactured by placing the used coffee grounds in $1 \mathrm{M} \mathrm{CaCl}_{2}$ solution and stirring for $24 \mathrm{~h}$ at room temperature, then dried at $110^{\circ} \mathrm{C}$ for $5 \mathrm{~h}$, followed by carbonizing at $600^{\circ} \mathrm{C}$ for $1 \mathrm{~h}$ and washing with $6 \mathrm{M} \mathrm{HCl}^{17)}$. The functional biochar was reported to have a $\mathrm{NO}_{3}{ }^{-}$adsorption capacity of $20 \mathrm{~g} \mathrm{~kg}^{-117}$. The mean particle diameter and specific surface area of the functional biochar were $938 \mu \mathrm{m}$ and $94.7 \mathrm{~m}^{2} \mathrm{~g}^{-1}$ on a dry-matter basis, respectively. The normal biochar was produced by drying the coffee grounds at $110^{\circ} \mathrm{C}$ and carbonizing at $600^{\circ} \mathrm{C}$ for $1 \mathrm{~h}^{17}$. Characteristics of the raw and biochar materials are presented in Table 1.

\section{Incubation tests}

Soil microcosms were constructed in $125 \mathrm{~mL}$ glass bottles. Each bottle received $5 \mathrm{~g}$ of air-dried soil or soil-biochar mixture. Treatments consisted of the addition of normal coffee waste biochar (NB) or functional coffee waste biochar (FB). The control, which received soil without biochar, was compared with the other treatments. All treatments were performed in triplicate. The application rate of biochar was $2 \%$ by weight $\left(24 \mathrm{t} \mathrm{ha}^{-1}\right.$, by assuming $0.1 \mathrm{~g}$ biochar over $5 \mathrm{~g}$ dried soil in a $125 \mathrm{~mL}$ glass bottle) which represents a common field application rate $^{18)}$. After adding biochar, soil microcosms were adjusted to $60 \%$ water holding capacity (WHC) and conditioned with $100 \mathrm{mg} \mathrm{N}-\mathrm{NO}_{3} \mathrm{~kg}^{-1}$ dry soil (adding $0.44 \mathrm{~mL}$ of $\mathrm{KNO}_{3} 1000 \mathrm{mg} \mathrm{N} \mathrm{L}^{-1}$ and 0.98 $\mathrm{mL}$ distilled-deionized water (NB-treated soil), and $1.13 \mathrm{~mL}$ distilled-deionized water (FB-treated soil)). These bottles were covered with a polyethylene plastic film to reduce evaporation while allowing air exchange, then incubated at $25^{\circ} \mathrm{C}, 30^{\circ} \mathrm{C}$ or $35^{\circ} \mathrm{C}$ for 21 days.

Before collecting gas samples, the incubation bottles were flushed by air for 30 seconds at a rate of $30 \mathrm{~mL} \mathrm{~s}^{-1}$ and then closed by a butyl rubber septum for $3 \mathrm{~h}$ on days $1,3,5,7,14$ and 21 .

Table 1 Properties of coffee waste materials

\begin{tabular}{lcccccc}
\hline \multicolumn{1}{c}{ Materials } & $\mathrm{pH}$ & $\mathrm{EC}\left(\mu \mathrm{S} \mathrm{cm}^{-1}\right)$ & $\mathrm{CEC}\left(\mathrm{cmol}_{\mathrm{c}} \mathrm{kg}^{-1}\right)$ & $\mathrm{TC}\left(\mathrm{g} \mathrm{kg}^{-1}\right)$ & $\mathrm{TN}\left(\mathrm{g} \mathrm{kg}^{-1}\right)$ & $\mathrm{C} / \mathrm{N}$ ratio \\
\hline Raw material & 6 & 721 & 40 & 521 & 25 & 21 \\
Normal biochar & 10 & 580 & 28 & 772 & 42 & 18 \\
Functional biochar & 5 & 474 & 12 & 634 & 28 & 23 \\
\hline
\end{tabular}

$\mathrm{pH}$ and EC were measured $(n=3)$ at a 1:10 ratio of material and deionized water (weight basis). 
Table 2 Properties of initial soil amended with/without biochar

\begin{tabular}{|c|c|c|c|c|c|}
\hline Treatments & & $\mathrm{pH}$ & $\begin{array}{c}\mathrm{EC} \\
\left(\mu \mathrm{S} \mathrm{cm}^{-1}\right)\end{array}$ & $\begin{array}{c}\mathrm{NO}_{3}-\mathrm{N} \\
\left(\mathrm{mg} \mathrm{N} \mathrm{kg}^{-1}\right)\end{array}$ & $\begin{array}{c}\mathrm{NH}_{4}-\mathrm{N} \\
\left(\mathrm{mg} \mathrm{N} \mathrm{kg}^{-1}\right)\end{array}$ \\
\hline Soil (CT) & 7.8 & $\pm 0.1^{\mathrm{a}}$ & $116 \pm 4^{b}$ & $12.0 \pm 0.4^{\mathrm{a}}$ & $2.6 \pm 0.2^{\mathrm{a}}$ \\
\hline Soil mixed with $2 \%$ normal biochar (NB) & 7.9 & $\pm 0^{\mathrm{a}}$ & $131 \pm 3^{b}$ & $10.8 \pm 0.4^{\mathrm{a}}$ & $\pm 0.1^{\mathrm{b}}$ \\
\hline Soil mixed with $2 \%$ functional biochar (FB) & 7.5 & $\pm 0^{\mathrm{b}}$ & $504 \pm 18^{\mathrm{a}}$ & $11.4 \pm 0.3^{\mathrm{ab}}$ & $\pm 0^{\mathrm{ab}}$ \\
\hline
\end{tabular}

Data are means \pm standard deviation. Different letters in each column denote significant differences $(p<0.05, n=3)$ according to Tukey's HSD test.

Air pressure of these samples was measured by an air pressure gauge (Handy manometer, Copal Electronics) just before the gas collection. After each sampling, deionized water was added to maintain a constant soil water content by weight. Concentrations of $\mathrm{N}_{2} \mathrm{O}$ and $\mathrm{CO}_{2}$ were measured by gas chromatographs (GC-8A, Shimadzu, Japan) equipped with an electron capture detector (ECD) and a thermal conductivity detector (TCD), respectively, and gas emission rates $\left(\mathrm{mg} \mathrm{kg}^{-1}\right.$ soil h$\left.{ }^{-1}\right)$ were calculated by using the following equation:

$$
V_{\mathrm{i}}=\rho \times C \times\left(V_{\mathrm{g}}+V_{\mathrm{L}} \times \alpha\right) \times 273 /(W \times(273+T)) / t
$$

where $V_{i}$ is $\mathrm{N}_{2} \mathrm{O}$ or $\mathrm{CO}_{2}$ emission $\left(\mathrm{mg} \mathrm{kg}^{-1} \mathrm{~h}^{-1}\right), t$ is closing time before collecting gas, $\rho$ is the density of $\mathrm{N}_{2} \mathrm{O}-\mathrm{N}\left(1.25 \mathrm{~kg} \mathrm{~m}^{-3}\right)$ or $\mathrm{CO}_{2}-\mathrm{C}\left(0.5357 \mathrm{~kg} \mathrm{~m}^{-3}\right)$ at $25^{\circ} \mathrm{C}, C$ is the $\mathrm{N}_{2} \mathrm{O}$ or $\mathrm{CO}_{2}$ concentration $\left(\mathrm{ppm}_{\mathrm{v}}\right), V_{g}$ $\left(\mathrm{m}^{3}\right)$ is the head volume, $V_{L}\left(\mathrm{~m}^{3}\right)$ is the volume of the liquid phase, $\alpha$ is the Bunsen absorption coefficient, $W(\mathrm{~kg})$ is the oven-dry weight of soil, and $T$ is the temperature at determination.

The same soil microcosms were incubated in parallel to determine soil characteristics $(\mathrm{pH}, \mathrm{EC}$, DOC, DTN) and mineral $\mathrm{N}\left(\mathrm{NO}_{3}-\mathrm{N}, \mathrm{NH}_{4}-\mathrm{N}\right)$ on days 0,7 and 21 of incubation.

The temperature sensitivity coefficient, $Q_{10}$, was calculated using this equation ${ }^{14)}$ :

$$
Q_{10}=\left(R_{2} / R_{1}\right)^{10 /\left(T_{2}-T_{1}\right)}
$$

where $T_{2}$ and $T_{1}$ are the incubation temperatures $\left({ }^{\circ} \mathrm{C}\right) ; R_{1}$ and $R_{2}$ are the emission rates of $T_{1}$ and $T_{2}$, respectively.

\section{Soil and biochar analyses}

All soil samples were subjected to measurement of $\mathrm{pH}$ and electricity conductivity (EC) at a soil: water ratio of $1: 5$ after shaking for $1 \mathrm{~h}$ at $175 \mathrm{rpm}$, using digital $\mathrm{pH}$ (F-23, Horiba, Japan) and EC meters (DS-14, Horiba, Japan), respectively. To measure $\mathrm{pH}$ and $\mathrm{EC}$ of $\mathrm{NB}$ and $\mathrm{FB}, \mathrm{a} 1: 10$ ratio of a material to deionized water (weight/basis) was used. Total carbon (TC) and total nitrogen (TN) contents of soil were determined by the dry combustion method using a CN coder (MT-700, Yanaco, Japan).
Dissolved organic carbon (DOC) and total extractable nitrogen (DTN) in the extracts (soil: water ratio of $1: 10$ ) filtered through $0.2 \mu \mathrm{m}$ filter were measured with a TOC analyzer (TOC-L $\mathrm{L}_{\mathrm{CSN}}$, Shimadzu, Japan). The soil mineral $\mathrm{N}$ was extracted with $2 \mathrm{M} \mathrm{KCl}$ (soil/water ratio of $1: 10$ ) and measured with a continuous flow analyzer (AutoAnalyzer QuAAtro 2-HR, Bltec, Japan) by colorimetric methods. Cation exchange capacity (CEC) of soil, NB and FB were determined by using the $1 M$ ammonium acetate extraction at $\mathrm{pH}$ 7.0.

\section{Statistical analysis}

Analysis of variance (ANOVA) with Tukey's HSD posthoc test was used to examine the significant differences $(p<0.05)$ in $\mathrm{N}_{2} \mathrm{O}$ and $\mathrm{CO}_{2}$ emissions, $\mathrm{pH}, \mathrm{EC}, \mathrm{NO}_{3}-\mathrm{N}, \mathrm{NH}_{4}-\mathrm{N}, \mathrm{DTN}$ and DOC among treatments. A two-way ANOVA was used to analyze the effects of biochar, temperature and their interactions on soil properties, soil mineral $\mathrm{N}$ and $\mathrm{N}_{2} \mathrm{O}$ and $\mathrm{CO}_{2}$ emissions. Pearson's correlation was performed for cumulative $\mathrm{N}_{2} \mathrm{O}$ as the main factor with dependences of $\mathrm{CO}_{2}, \mathrm{pH}, \mathrm{EC}, \mathrm{NO}_{3}-\mathrm{N}, \mathrm{NH}_{4}-\mathrm{N}$, DTN and DOC among treatments after 21 incubation days. All statistical calculations were performed using SPSS software (SPSS 16.0).

\section{RESULTS}

\section{Soil properties}

Initial $\mathrm{pH}$ values of $\mathrm{CT}, \mathrm{NB}$ and $\mathrm{FB}$ were 7.8 , 7.9 and 7.5, respectively. Addition of normal biochar did not significantly change $\mathrm{pH}$ or EC while addition of functional biochar reduced $\mathrm{pH}$ and increased EC (Table 2, $p<0.05$ ) compared to the control. Initial $\mathrm{NO}_{3}-\mathrm{N}$ and $\mathrm{NH}_{4}-\mathrm{N}$ were not significantly different in the FB while they were lower in the NB than the CT (Table 2, $p<0.05$ ). 

TYPES OF BIOCHAR AT THREE TEMPERATURES

Table 3 Soil characteristics on day 21 of incubation at different temperatures

\begin{tabular}{|c|c|c|c|c|c|c|c|c|c|c|}
\hline & & & CT & & & NB & & & FB & \\
\hline \multirow{4}{*}{$\begin{array}{l}\text { Prior to } \\
\text { incubation }\end{array}$} & $\mathrm{NO}_{3}-\mathrm{N}\left(\mathrm{mg} \mathrm{N} \mathrm{kg}^{-1}\right)$ & 104.7 & \pm & $2.2^{\mathrm{a}}$ & 109.4 & \pm & $3.3^{\mathrm{a}}$ & 109.0 & \pm & $6.1^{\mathrm{a}}$ \\
\hline & $\mathrm{NH}_{4}-\mathrm{N}\left(\mathrm{mg} \mathrm{N} \mathrm{kg}^{-1}\right)$ & 3.0 & \pm & $0.1^{\mathrm{a}}$ & 2.3 & \pm & $0.2^{\mathrm{b}}$ & 2.4 & \pm & $0.3^{\mathrm{b}}$ \\
\hline & $\mathrm{DOC}\left(\mathrm{mg} \mathrm{C} \mathrm{kg}^{-1}\right)$ & 69.7 & \pm & $3.7^{\mathrm{a}}$ & 70.4 & \pm & $5.9^{\mathrm{a}}$ & 53.7 & \pm & $7.5^{\mathrm{b}}$ \\
\hline & DTN (mg N kg-1) & 103.8 & \pm & $3.5^{\mathrm{a}}$ & 108.4 & \pm & $2.0^{\mathrm{a}}$ & 38.8 & \pm & $3.1^{\mathrm{b}}$ \\
\hline \multirow{4}{*}{$25^{\circ} \mathrm{C}$} & $\mathrm{NO}_{3}-\mathrm{N}\left(\mathrm{mg} \mathrm{N} \mathrm{kg}^{-1}\right)$ & 111.6 & \pm & $5.7^{\mathrm{aA}}$ & 59.3 & \pm & $2.1^{\mathrm{bA}}$ & 113.7 & \pm & $3.5^{\mathrm{aA}}$ \\
\hline & $\mathrm{NH}_{4}-\mathrm{N}\left(\mathrm{mg} \mathrm{N} \mathrm{kg}^{-1}\right)$ & 0.9 & \pm & $0.1^{\mathrm{aA}}$ & 0.6 & \pm & $0.1^{\mathrm{bA}}$ & 0.5 & \pm & $0.1^{\mathrm{bA}}$ \\
\hline & $\mathrm{DOC}\left(\mathrm{mg} \mathrm{C} \mathrm{kg}^{-1}\right)$ & 37.2 & \pm & $6.2^{\mathrm{aA}}$ & 48.9 & \pm & $6.2^{\mathrm{aA}}$ & 25.5 & \pm & $1.7^{\mathrm{bA}}$ \\
\hline & DTN (mg N kg-1) & 114.9 & \pm & $4.4^{\mathrm{aA}}$ & 59.7 & \pm & $0.7^{\mathrm{bA}}$ & 53.9 & \pm & $4.2^{\mathrm{bA}}$ \\
\hline \multirow{4}{*}{$30^{\circ} \mathrm{C}$} & $\mathrm{NO}_{3}-\mathrm{N}\left(\mathrm{mg} \mathrm{N} \mathrm{kg}^{-1}\right)$ & 109.2 & \pm & $2.0^{\mathrm{aA}}$ & 48.4 & \pm & $3.6^{\mathrm{bA}}$ & 107.7 & \pm & $7.3^{\mathrm{aA}}$ \\
\hline & $\mathrm{NH}_{4}-\mathrm{N}\left(\mathrm{mg} \mathrm{N} \mathrm{kg}^{-1}\right)$ & 0.3 & \pm & $0.1^{\mathrm{bA}}$ & 0.2 & \pm & $0.1^{\mathrm{bA}}$ & 0.5 & \pm & $0.2^{\mathrm{aA}}$ \\
\hline & $\mathrm{DOC}\left(\mathrm{mg} \mathrm{C} \mathrm{kg}{ }^{-1}\right)$ & 31.0 & \pm & $3.1^{\mathrm{bA}}$ & 50.3 & \pm & $3.9^{\mathrm{aA}}$ & 29.0 & \pm & $2.1^{\mathrm{bA}}$ \\
\hline & DTN (mg N kg $\left.{ }^{-1}\right)$ & 113.9 & \pm & $2.1^{\mathrm{aA}}$ & 43.9 & \pm & $1.6^{\mathrm{cA}}$ & 52.8 & \pm & $2.7^{\mathrm{bA}}$ \\
\hline \multirow{4}{*}{$35^{\circ} \mathrm{C}$} & $\mathrm{NO}_{3}-\mathrm{N}\left(\mathrm{mg} \mathrm{N} \mathrm{kg}^{-1}\right)$ & 109.6 & \pm & $4.1^{\mathrm{aA}}$ & 42.3 & \pm & $0.8^{\mathrm{bA}}$ & 102.5 & \pm & $8.9^{\mathrm{aA}}$ \\
\hline & $\mathrm{NH}_{4}-\mathrm{N}\left(\mathrm{mg} \mathrm{N} \mathrm{kg}^{-1}\right)$ & 0.5 & \pm & $0.1^{\mathrm{aA}}$ & 0.4 & \pm & $0.1^{\mathrm{abA}}$ & 0.3 & \pm & $0.1^{\mathrm{bA}}$ \\
\hline & $\mathrm{DOC}\left(\mathrm{mg} \mathrm{C} \mathrm{kg}^{-1}\right)$ & 33.4 & \pm & $2.9^{\mathrm{aA}}$ & 40.6 & \pm & $7.6^{\mathrm{aA}}$ & 17.1 & \pm & $4.8^{\mathrm{bA}}$ \\
\hline & DTN (mg N kg-1) & 115.8 & \pm & $4.0^{\mathrm{aA}}$ & 41.0 & \pm & $2.1^{\mathrm{cA}}$ & 51.0 & \pm & $1.1^{\mathrm{bA}}$ \\
\hline
\end{tabular}

Data are means \pm standard deviation. Different lowercase letters indicate difference among treatments. Different uppercase letters indicate difference among temperatures $(p<0.05, n=3)$.
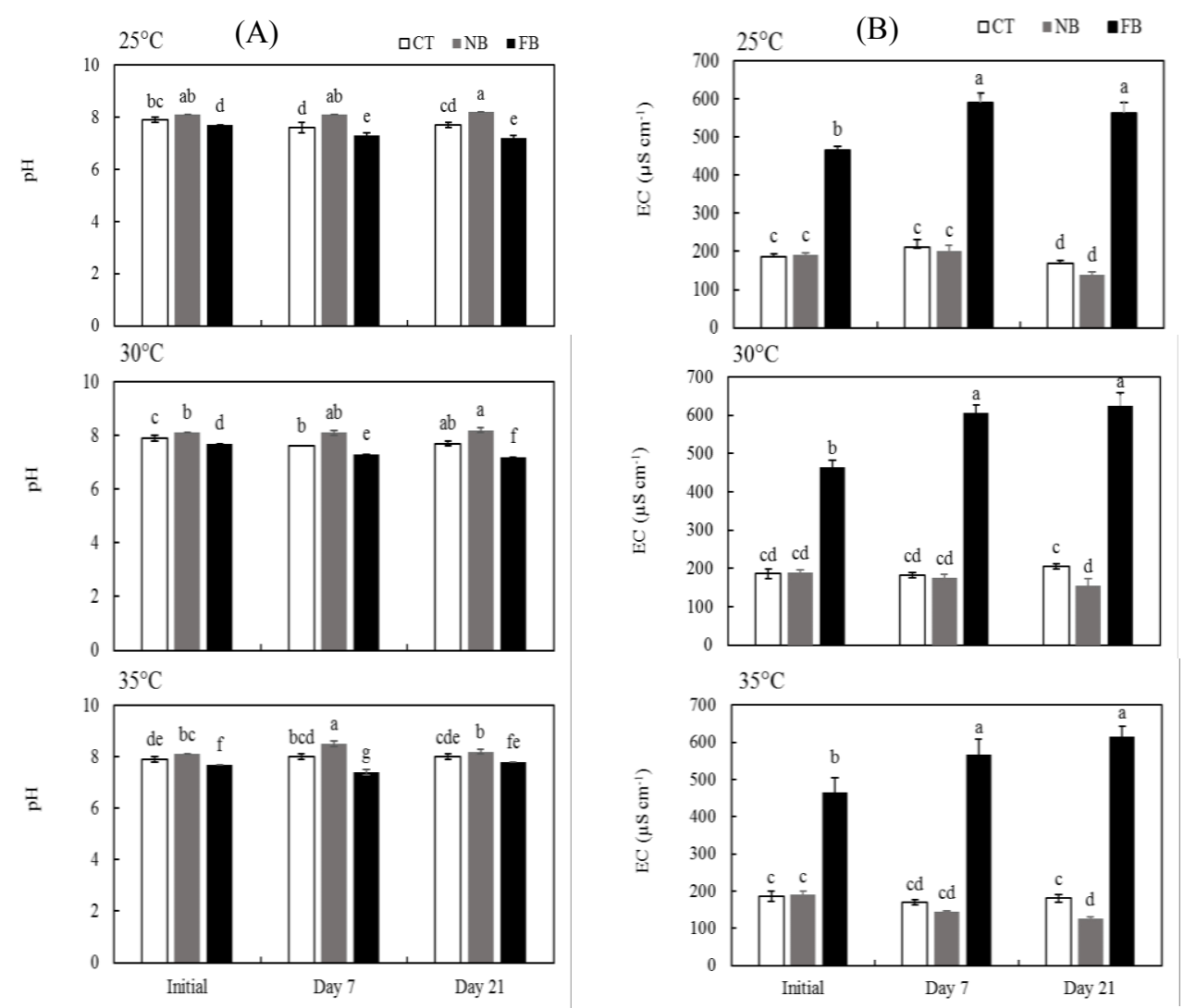

Fig. 1 Soil $\mathrm{pH}(\mathrm{A})$ and $\mathrm{EC}(\mathrm{B})$ changes at different temperatures $\left(25^{\circ} \mathrm{C}, 30^{\circ} \mathrm{C}\right.$ and $\left.35^{\circ} \mathrm{C}\right)$ Different letters $(\mathrm{a}, \mathrm{b}, \mathrm{c}, \mathrm{d}$, e and $\mathrm{f})$ indicate significant differences on different days $(p<0.05)$. Bars indicate standard deviation $(n=3)$. 
Changes in soil pH, EC, mineral $\mathrm{N}$ contents and DOC during incubation

The $\mathrm{pH}$ on day 21 was alkaline in all treatments, and was higher in the NB treatment than in CT and FB treatments (Fig. 1a, $p<0.05$ ). The functional biochar addition decreased soil $\mathrm{pH}$ by $0.2-1.1$ units depending on temperature and increased soil EC (Fig. 1b, $p<0.05$ ) while $\mathrm{NB}$ application had no effect on soil EC during the incubation period. At the beginning of the experiment, $100 \mathrm{mg} \mathrm{NO}-\mathrm{N}$ $\mathrm{kg}^{-1}$ dry soil was added to the soil samples. On day 7 , $\mathrm{NO}_{3}-\mathrm{N}$ contents in $\mathrm{CT}$ and $\mathrm{FB}$ treatments were not different from those prior to incubation while it was significantly decreased in the NB treatment. On day
21, the $\mathrm{NO}_{3}-\mathrm{N}$ content continued to decrease to 42-59 $\mathrm{mg} \mathrm{kg}^{-1}$ in the NB treatment (Table $3, p<$ 0.05 ) compared to the initial values. The $\mathrm{NH}_{4}-\mathrm{N}$ content in all treatments was reduced after 21 incubation days (Table $3, p<0.05$ ) compared to the initial.

In all treatments, DOC concentrations decreased and was the lowest in the FB treatment. Compared to the initial content, DTN decreased in the NB treatment, while it increased in the FB after 21 incubation days. No significant difference in DOC and DTN was observed at each temperature between prior to incubation and on day 21 (Table $3, p<0.05$ ).

Table $4 \mathrm{~N}_{2} \mathrm{O}$ and $\mathrm{CO}_{2}$ fluxes on day 1 at three temperatures

\begin{tabular}{|c|c|c|c|c|c|c|c|c|}
\hline \multirow{2}{*}{ Temperature } & \multicolumn{3}{|c|}{$\mathrm{N}_{2} \mathrm{O}\left(\mathrm{mg} \mathrm{N} \mathrm{kg}^{-1} \mathrm{~d}^{-1}\right)$} & \multicolumn{5}{|c|}{$\mathrm{CO}_{2}\left(\mathrm{mg} \mathrm{C} \mathrm{kg}^{-1} \mathrm{~d}^{-1}\right)$} \\
\hline & $\mathrm{CT}$ & NB & FB & $\mathrm{CT}$ & & NB & & FB \\
\hline $25^{\circ} \mathrm{C}$ & $6.5 \pm 0.3^{c}$ & $7.0 \pm 0.3^{\mathrm{c}}$ & $10.2 \pm 1.0^{\mathrm{b}}$ & $50.9 \pm 1.4^{\mathrm{cd}}$ & 48.0 & $\pm 3.9^{\mathrm{cd}}$ & 29.9 & $\pm 11.9^{\mathrm{d}}$ \\
\hline $30^{\circ} \mathrm{C}$ & $4.4 \pm 0.4^{\mathrm{d}}$ & $6.3 \pm 0.1^{\mathrm{c}}$ & $6.9 \pm 1.2^{\mathrm{c}}$ & $95.3 \pm 3.7^{b}$ & 63.6 & $\pm 11.2^{\mathrm{bcd}}$ & 36.4 & $\pm 9.5^{\mathrm{d}}$ \\
\hline $35^{\circ} \mathrm{C}$ & $28.6 \pm 0.4^{\mathrm{a}}$ & $2.1 \pm 0.2^{\mathrm{e}}$ & $3.6 \pm 0.4^{\mathrm{de}}$ & $290.4 \pm 23.5^{\mathrm{a}}$ & 76.6 & $\pm 11.4^{\mathrm{bc}}$ & 60.3 & $\pm 15.5^{\mathrm{cd}}$ \\
\hline
\end{tabular}

Data are means \pm standard deviation. Different letters indicate difference among treatments $(p<0.05, n=3)$.
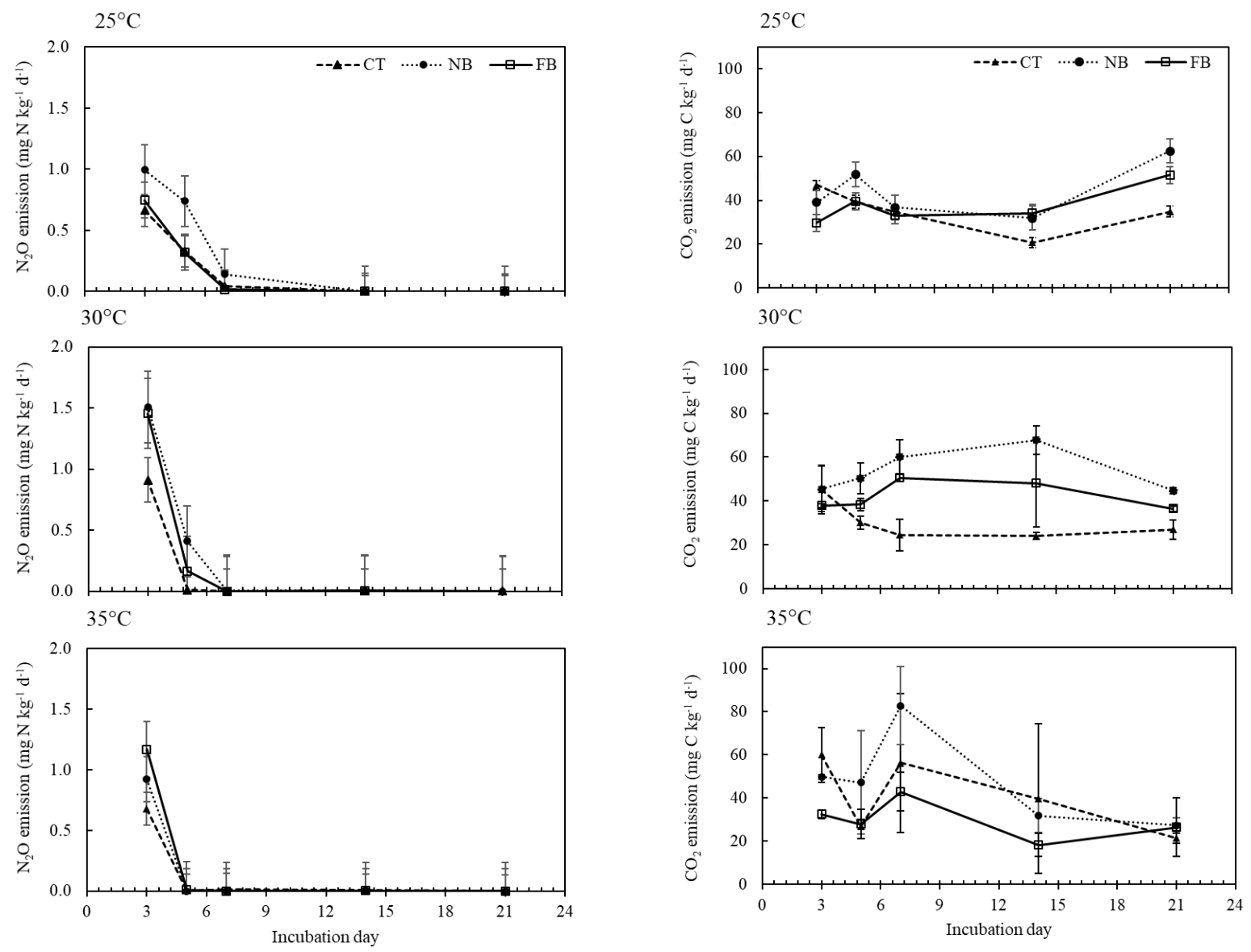

Fig. $2 \mathrm{~N}_{2} \mathrm{O}$ (a) and $\mathrm{CO}_{2}$ (b) emissions in different treatments at each temperature from day 3 to day 21 Bars indicate standard deviation $(n=3)$. 
Table 5 Cumulative $\mathrm{N}_{2} \mathrm{O}$ and $\mathrm{CO}_{2}$ emissions for 21 days of incubation

\begin{tabular}{|c|c|c|c|c|c|c|c|}
\hline \multirow{2}{*}{ Temp. } & \multicolumn{3}{|c|}{$\mathrm{N}_{2} \mathrm{O}\left(\mathrm{mg} \mathrm{N} \mathrm{kg}^{-1}\right)$} & \multicolumn{4}{|c|}{$\mathrm{CO}_{2}\left(\mathrm{mg} \mathrm{C} \mathrm{kg}^{-1}\right)$} \\
\hline & $\mathrm{CT}$ & NB & FB & $\mathrm{CT}$ & NB & & FB \\
\hline $25^{\circ} \mathrm{C}$ & $15.1 \pm 1.0^{c}$ & $18.1 \pm 0.6^{\mathrm{c}}$ & $22.6 \pm 1.8^{\mathrm{b}}$ & $696.8 \pm 16.3^{\mathrm{d}}$ & $885.2 \pm 134.4^{\mathrm{cd}}$ & 767.1 & $\pm 12.9^{\mathrm{cd}}$ \\
\hline $30^{\circ} \mathrm{C}$ & $10.7 \pm 0.7^{\mathrm{d}}$ & $16.4 \pm 0.1^{\mathrm{c}}$ & $17.1 \pm 2.5^{\mathrm{c}}$ & $713.2 \pm 55.3^{\mathrm{d}}$ & $1219.5 \pm 31.6^{\mathrm{ab}}$ & 916.6 & $\pm 130.7^{\mathrm{bcd}}$ \\
\hline $35^{\circ} \mathrm{C}$ & $58.6 \pm 0.7^{\mathrm{a}}$ & $6.1 \pm 0.2^{\mathrm{e}}$ & $9.6 \pm 0.6^{\mathrm{d}}$ & $1359.1 \pm 240.9^{\mathrm{a}}$ & $1036.9 \pm 88.9^{\mathrm{bc}}$ & 653.3 & $\pm 86.2^{\mathrm{d}}$ \\
\hline
\end{tabular}

Data are means \pm standard deviation. Different letters indicate difference among treatments $(p<0.05, n=3)$.

\section{$\mathrm{N}_{2} \mathrm{O}$ and $\mathrm{CO}_{2}$ emissions from different biochar materials}

$\mathrm{N}_{2} \mathrm{O}$ fluxes in all treatments were the highest on day 1 (Table 4), which is in agreement with the previous study ${ }^{19)}$ and then decreased until the end of incubation (Fig. 2a, $p<0.05$ ). The emissions of $\mathrm{N}_{2} \mathrm{O}$ on day 1 were in the range of $2.1-7.0 \mathrm{mg} \mathrm{N} \mathrm{kg}^{-1}$ from the NB, 3.6-10.2 mg N kg-1 from the $\mathrm{FB}$ and 4.4-28.6 mg N kg-1 from the CT (Table 4, $p<0.05$ ). The emissions of $\mathrm{N}_{2} \mathrm{O}$ on day 1 accounted for $35-49 \%$ of the total emission for 21 incubation days. Cumulative $\mathrm{N}_{2} \mathrm{O}$ emissions from $\mathrm{FB}$ amended soil were higher than those from the NB regardless of temperature (Tables $4 \& 5, p<0.05$ ). These outcomes were different from those predicted by the hypothesis because the low $\mathrm{pH}$ of $\mathrm{FB}$ as compared to $\mathrm{NB}$ could limit $\mathrm{N}_{2}$ formation and therefore increased $\mathrm{N}_{2} \mathrm{O} /\left(\mathrm{N}_{2}+\mathrm{N}_{2} \mathrm{O}\right)$ product ratios.

Fluxes of $\mathrm{CO}_{2}$ were generally the largest on day 1 and continued until the end of the incubation. $\mathrm{CO}_{2}$ emissions from soil amended with FB and NB were respectively, $29.9-60.3 \mathrm{mg} \mathrm{C} \mathrm{kg}^{-1}$ and $48.0-76.6 \mathrm{mg}$ $\mathrm{C} \mathrm{kg}^{-1}$ and from CT was 50.9-290.4 mg C kg-1. In addition, $\mathrm{FB}$ had a neutral or negative effect on cumulative $\mathrm{CO}_{2}$ emission as compared to $\mathrm{NB}$ after 21 incubation days (Table 5 and Fig. 2 b, $p<0.05$ ).

Different biochar materials had significant effects on both cumulative $\mathrm{N}_{2} \mathrm{O}$ and $\mathrm{CO}_{2}$ (Table $6, p$ $<0.05$ ) but the $\mathrm{N}_{2} \mathrm{O}$ and $\mathrm{CO}_{2}$ responses to biochar materials were different. The FB had higher cumulative $\mathrm{N}_{2} \mathrm{O}$ and lower cumulative $\mathrm{CO}_{2}$ emissions than the NB.

\section{High temperature effects on $\mathrm{N}_{2} \mathrm{O}$ and $\mathrm{CO}_{2}$ emissions}

Amendment with biochar had negative or positive priming effects on cumulative $\mathrm{N}_{2} \mathrm{O}$ and $\mathrm{CO}_{2}$ fluxes as compared to the control, which was dependent on the temperature (Table $5, p<0.05$ ). At $25^{\circ} \mathrm{C}, \mathrm{N}_{2} \mathrm{O}$ fluxes were higher in the FB treatment than in NB and CT treatments. At $30^{\circ} \mathrm{C}$, both biochar treatments had higher $\mathrm{N}_{2} \mathrm{O}$ fluxes than the CT. At $35^{\circ} \mathrm{C}$, biochar application reduced cumulative $\mathrm{N}_{2} \mathrm{O}$ emission by $84 \%$ for $\mathrm{FB}$ and $90 \%$ for NB compared to the CT (Table 5, $p<0.05$ ).

At $25^{\circ} \mathrm{C}$, cumulative $\mathrm{CO}_{2}$ emissions in all treatments were not significantly different but at $30^{\circ} \mathrm{C}$, it was higher in the NB treatment than in the others. At $35^{\circ} \mathrm{C}$, a significant reduction in cumulative $\mathrm{CO}_{2}$ emissions was observed: $24 \%$ reduction for $\mathrm{NB}$ and $52 \%$ reduction for $\mathrm{FB}$ compared to the CT (Table 5, $p<0.05$ ).

A two-way ANOVA showed that temperature had significant effects on both cumulative $\mathrm{N}_{2} \mathrm{O}$ and $\mathrm{CO}_{2}$ fluxes (Table 6, $p<0.001$ ). When considering temperature effects on each amendment, there was a positive correlation between cumulative $\mathrm{N}_{2} \mathrm{O}$ emission and temperature in the $\mathrm{CT}$ as it increased $10^{\circ} \mathrm{C}$ (Tables $5 \& 6, p<0.05$ ), which is consistent with other studies ${ }^{2012) 14) 21)}$. On the contrary, a negative correlation between temperature and cumulative $\mathrm{N}_{2} \mathrm{O}$ emission was observed in $\mathrm{NB}$ and FB treatments (Tables $5 \& 6, p<0.05$ ). Cumulative $\mathrm{CO}_{2}$ emission had a positive correlation as temperature of the $\mathrm{CT}$ increased $10^{\circ} \mathrm{C}$, while there has no response of cumulative $\mathrm{CO}_{2}$ emission to temperature change in $\mathrm{NB}$ and $\mathrm{FB}$ treatments (Tables $5 \& 6, p<0.05$ ).

The $Q_{10}$ values of $\mathrm{N}_{2} \mathrm{O}$ and $\mathrm{CO}_{2}$ varied with the incubation temperature (Table 7). $Q_{10}$ values of $\mathrm{CO}_{2}$ were higher than those of $\mathrm{N}_{2} \mathrm{O}$, except for the $\mathrm{CT}$ at $25-35^{\circ} \mathrm{C}$. $Q_{10}$ values of $\mathrm{N}_{2} \mathrm{O}$ and $\mathrm{CO}_{2}$ of the biochar treatments at $25-30^{\circ} \mathrm{C}$ were higher than at $25-35^{\circ} \mathrm{C}$. $Q_{10}$ values of $\mathrm{CT}$ at $25-35^{\circ} \mathrm{C}$ were the highest among the treatments. 
Table 6 Responses of $\mathrm{N}_{2} \mathrm{O}$ and $\mathrm{CO}_{2}$ to temperature and biochar materials in a two-way ANOVA

\begin{tabular}{l|lll|lll}
\hline \multirow{2}{*}{ Factors } & \multicolumn{3}{c|}{$\mathrm{N}_{2} \mathrm{O}$} & \multicolumn{3}{c}{$\mathrm{CO}_{2}$} \\
\cline { 2 - 7 } & $d f$ & $f$ & $p$ & $d f$ & $f$ & $p$ \\
\hline Temperature (Temp) & 2 & 166.8 & $<0.0001$ & 2 & 10.4 & $<0.05$ \\
Biochar materials (Treatment) & 2 & 391.2 & $<0.0001$ & 2 & 12.9 & $<0.0001$ \\
Temp $\times$ Treatment & 4 & 774.0 & $<0.0001$ & 4 & 17.3 & $<0.0001$ \\
\hline
\end{tabular}

\section{DISCUSSIONS}

\section{$\mathrm{N}_{2} \mathrm{O}$ emissions from different biochar materials}

Nitrous oxide emissions generally originate from denitrification or nitrification processes. The contribution of nitrification to $\mathrm{N}_{2} \mathrm{O}$ emission under aerobic conditions is likely to be small $(<0.2 \%$ for the majority of measurements $)^{22)}$ and denitrification played a major role in $\mathrm{N}_{2} \mathrm{O}$ production in the vegetable soil under the experimental conditions ${ }^{23}$. In addition, a low $\mathrm{NH}_{4}-\mathrm{N}$ content compared to $\mathrm{NO}_{3}-\mathrm{N}$ in all treatments indicated that $\mathrm{N}_{2} \mathrm{O}$ emissions in this study were from denitrification. The main factors controlling denitrification and $\mathrm{N}_{2} \mathrm{O}$ production were $\mathrm{pH}$ and $\mathrm{NO}_{3}-\mathrm{N}$ availability ${ }^{24) 25) 26)}$. However, our results showed that only the $\mathrm{NO}_{3}-\mathrm{N}$ content in the NB treatment was reduced with time (Table 3) and showed no change in the FB treatments (Table 3). $\mathrm{N}_{2} \mathrm{O}$ emissions from $\mathrm{NB}$ and FB accounted for 6-17\% and 9-21\%, respectively, of the initial $\mathrm{NO}_{3}-\mathrm{N}$ input, which was also highly correlated with increased soil $\mathrm{pH}$ after alkaline biochar application (NB) and $\mathrm{NO}_{3}-\mathrm{N}$ reduction (Table 8, Fig. 1a), which are known to control denitrification in soil ${ }^{19}$ ). High $\mathrm{NO}_{3}-\mathrm{N}$ content in the FB-amended soil could be from nitrification via soil mineralization, converting $\mathrm{NH}_{4}-\mathrm{N}$ to $\mathrm{NO}_{3}-\mathrm{N}$ (reduction of $\mathrm{NH}_{4}-\mathrm{N}$ content after 21 incubation days) and releasing $\mathrm{N}_{2} \mathrm{O}$ and $\mathrm{N}_{2}$. The low $\mathrm{pH}$ of $\mathrm{FB}$ could limit the $\mathrm{N}_{2}$ formation or may increase the $\mathrm{N}_{2} \mathrm{O}$ product ratios ${ }^{27)}\left(\mathrm{N}_{2} \mathrm{O} /\left(\mathrm{N}_{2}+\mathrm{N}_{2} \mathrm{O}\right)\right)$, and explain the higher $\mathrm{N}_{2} \mathrm{O}$ emission from $\mathrm{FB}$ than from $\mathrm{NB}$.

\section{$\mathrm{CO}_{2}$ emissions from different biochar materials}

The lower $\mathrm{CO}_{2}$ emissions in the $\mathrm{FB}$ treatment were probably due to the low DOC and TC contents in FB as compared to NB (Tables $1 \& 3, p<0.05$ ). In addition, the effect of biochar addition on $\mathrm{CO}_{2}$ emission was dependent on the characteristics of biochar, as observed by Spokas and Reicosky (2009). Different responses to soil $\mathrm{CO}_{2}$ production from 16 different biochar materials (two biochars that suppressed $\mathrm{CO}_{2}$ respiration, five chars that significantly stimulated $\mathrm{CO}_{2}$ respiration compared to the soil controls and nine with no significant alteration) were shown although they were from the same feedstock and similar pyrolysis temperatures ${ }^{9)}$. The role of biochar in $\mathrm{CO}_{2}$ reduction was different depending on the temperature. At $25^{\circ} \mathrm{C}$, there was no significant difference between the control and biochar-treated soils (Table 5, $p>0.05$ ). At $30^{\circ} \mathrm{C}$ NB was a source of $\mathrm{CO}_{2}$ emissions, and emitted $\mathrm{CO}_{2} 1.7$ times greater than CT (Table 5, $p<0.05$ ). However, at $35^{\circ} \mathrm{C} \mathrm{NB}$ and $\mathrm{FB}$ were sinks of $\mathrm{CO}_{2}$, because they can absorb $\mathrm{CO}_{2}$ with reductions of $52 \%$ and $79 \%$, respectively, compared with CT (Table 5, $p<0.05$ ).

\section{Effects of temperature on $\mathrm{N}_{2} \mathrm{O}$ and $\mathrm{CO}_{2}$ emissions}

At $35^{\circ} \mathrm{C}$, biochar addition reduced $\mathrm{N}_{2} \mathrm{O}$ and $\mathrm{CO}_{2}$ emissions while it had a neutral or positive effect at lower temperatures. The difference in temperature response between $\mathrm{N}_{2} \mathrm{O}$ and $\mathrm{CO}_{2}$ emissions may reflect the different rate of microbial processes mediating respiration and denitrification. In the laboratory, temperature is generally assumed to have an exponential relationship with the rate of soil $\mathrm{N}_{2} \mathrm{O}$ emission below $30^{\circ} \mathrm{C}^{28)}$. In addition, temperature effects may be complicated by accumulation of $\mathrm{NO}_{2}^{-}$with the possibility of chemo-denitrification ${ }^{29}$, and repression of $\mathrm{N}_{2}$ formation due to high $\mathrm{NO}_{2}{ }^{-}$or $\mathrm{NO}_{3}{ }^{-}$levels will reduce $\mathrm{N}_{2} \mathrm{O}$ production.

Table $7 Q_{10}$ values of $\mathrm{N}_{2} \mathrm{O}$ and $\mathrm{CO}_{2}$ emissions for 21 incubation days at different temperatures

\begin{tabular}{lccc}
\hline & $\mathrm{N}_{2} \mathrm{O}$ & $25-30^{\circ} \mathrm{C}$ & $25-35^{\circ} \mathrm{C}$ \\
\hline $\mathrm{CT}$ & 0.50 & 3.89 \\
$\mathrm{NB}$ & 0.83 & 0.34 \\
$\mathrm{FB}$ & 0.58 & 0.42 \\
\hline & $\mathrm{CO}_{2}$ & $25-30^{\circ} \mathrm{C}$ & $25-35^{\circ} \mathrm{C}$ \\
\hline $\mathrm{CT}$ & 1.05 & 1.95 \\
$\mathrm{NB}$ & 1.90 & 1.17 \\
$\mathrm{FB}$ & 1.43 & 0.85 \\
\hline
\end{tabular}



TYPES OF BIOCHAR AT THREE TEMPERATURES

Table 8 Pearson's correlation for $\mathrm{N}_{2} \mathrm{O}$ and $\mathrm{CO}_{2}$ emissions and soil properties after 21 days of incubation in different treatments

\begin{tabular}{|c|c|c|c|c|c|c|c|c|}
\hline $\mathrm{CT}$ & $\mathrm{N}_{2} \mathrm{O}$ & $\mathrm{CO}_{2}$ & $\mathrm{NO}_{3}-\mathrm{N}$ & $\mathrm{NH}_{4}-\mathrm{N}$ & DOC & DTN & $\mathrm{pH}$ & $\mathrm{EC}$ \\
\hline $\mathrm{N}_{2} \mathrm{O}$ & - & $0.930^{* *}$ & -0.117 & 0.323 & -0.022 & 0.195 & -0.080 & -0.253 \\
\hline $\mathrm{CO}_{2}$ & $0.930^{* *}$ & - & -0.092 & 0.453 & -0.184 & 0.351 & 0.051 & -0.221 \\
\hline $\mathrm{NO}_{3}-\mathrm{N}$ & -0.117 & -0.092 & - & 0.240 & 0.119 & 0.827 & -0.390 & -0.163 \\
\hline $\mathrm{NH}_{4}-\mathrm{N}$ & 0.323 & 0.453 & 0.240 & - & 0.133 & 0.463 & -0.538 & -0.666 \\
\hline DOC & -0.022 & -0.184 & 0.119 & 0.133 & - & -0.007 & -0.597 & -0.360 \\
\hline DTN & 0.195 & 0.351 & 0.827 & 0.463 & -0.007 & - & -0.203 & -0.113 \\
\hline $\mathrm{pH}$ & -0.080 & 0.051 & -0.390 & -0.538 & -0.597 & -0.203 & - & 0.852 \\
\hline $\mathrm{EC}$ & -0.253 & -0.221 & -0.163 & -0.666 & -0.360 & -0.113 & 0.852 & - \\
\hline NB & $\mathrm{N}_{2} \mathrm{O}$ & $\mathrm{CO}_{2}$ & $\mathrm{NO}_{3}-\mathrm{N}$ & $\mathrm{NH}_{4}-\mathrm{N}$ & DOC & DTN & $\mathrm{pH}$ & $\mathrm{EC}$ \\
\hline $\mathrm{N}_{2} \mathrm{O}$ & - & -0.063 & $0.811^{* *}$ & -0.358 & 0.624 & 0.703 & $0.571^{* *}$ & 0.537 \\
\hline $\mathrm{CO}_{2}$ & -0.063 & - & -0.456 & -0.470 & 0.159 & -0.680 & 0.520 & 0.421 \\
\hline $\mathrm{NO}_{3}-\mathrm{N}$ & $0.811^{* *}$ & -0.456 & - & 0.028 & 0.400 & 0.910 & 0.081 & 0.152 \\
\hline $\mathrm{NH}_{4}-\mathrm{N}$ & -0.358 & -0.470 & 0.028 & - & -0.400 & 0.190 & -0.449 & -0.580 \\
\hline DOC & 0.624 & 0.159 & 0.400 & -0.400 & - & 0.402 & 0.451 & 0.586 \\
\hline DTN & 0.703 & -0.680 & 0.910 & 0.190 & 0.402 & - & -0.033 & 0.060 \\
\hline $\mathrm{pH}$ & $0.571^{* *}$ & 0.520 & 0.081 & -0.449 & 0.451 & -0.033 & - & 0.818 \\
\hline $\mathrm{EC}$ & 0.537 & 0.421 & 0.152 & -0.580 & 0.586 & 0.060 & 0.818 & - \\
\hline FB & $\mathrm{N}_{2} \mathrm{O}$ & $\mathrm{CO}_{2}$ & $\mathrm{NO}_{3}-\mathrm{N}$ & $\mathrm{NH}_{4}-\mathrm{N}$ & DOC & DTN & $\mathrm{pH}$ & $\mathrm{EC}$ \\
\hline $\mathrm{N}_{2} \mathrm{O}$ & - & $0.316^{* *}$ & 0.448 & 0.448 & 0.672 & 0.455 & $-0.838^{* *}$ & -0.418 \\
\hline $\mathrm{CO}_{2}$ & $0.316^{* *}$ & - & 0.380 & 0.158 & 0.736 & 0.162 & -0.744 & 0.112 \\
\hline $\mathrm{NO}_{3}-\mathrm{N}$ & 0.448 & 0.380 & - & -0.322 & 0.459 & 0.075 & -0.455 & -0.696 \\
\hline $\mathrm{NH}_{4}-\mathrm{N}$ & 0.448 & 0.158 & -0.322 & - & 0.306 & -0.175 & -0.413 & 0.169 \\
\hline DOC & 0.672 & 0.736 & 0.459 & 0.306 & - & 0.182 & -0.885 & -0.107 \\
\hline DTN & 0.455 & 0.162 & 0.075 & -0.175 & 0.182 & - & -0.401 & -0.220 \\
\hline $\mathrm{pH}$ & $-0.838^{* *}$ & -0.744 & -0.455 & -0.413 & -0.885 & -0.401 & - & 0.190 \\
\hline $\mathrm{EC}$ & -0.418 & 0.112 & -0.696 & 0.169 & -0.107 & -0.220 & 0.190 & - \\
\hline
\end{tabular}

${ }^{* *}$ Significant at $p<0.01 ;{ }^{*}$ significant at $p<0.05, n=9$.

Keeney (1979) showed that the denitrification product $\left(\mathrm{N}_{2} \mathrm{O}+\mathrm{N}_{2}\right)$ at $25^{\circ} \mathrm{C}$ accounted for about $44 \% \mathrm{NO}_{3}-\mathrm{N}$ input, while at $40^{\circ} \mathrm{C}$, nearly four times as much as gaseous $\mathrm{N}$ was evolved by 4 days at $25^{\circ} \mathrm{C}$. Although, the $\mathrm{N}_{2} \mathrm{O} / \mathrm{N}_{2}$ ratio has been shown to decrease with increasing temperature during denitrification $^{30)}$, the higher $\mathrm{N}_{2} \mathrm{O}$ emission in the soil without biochar amendment was not observed in the present study. In this study, we did not discover the mechanisms of increasing temperature effects on $\mathrm{N}_{2} \mathrm{O}$ and $\mathrm{CO}_{2}$ emissions with biochar amendment. Further study is required to identify simultaneous effects of biochar and temperature on $\mathrm{N}_{2} \mathrm{O}$ and $\mathrm{CO}_{2}$ emissions.

Once the temperature changed $10^{\circ} \mathrm{C}\left(25-35^{\circ} \mathrm{C}\right)$, $\mathrm{N}_{2} \mathrm{O}$ emission from the CT was more sensitive to temperature change than from biochar-amended soil. However, little is known about the temperature sensitivity of $\mathrm{N}_{2} \mathrm{O}$ emission from biochar-added soils. Most studies reported that $\mathrm{N}_{2} \mathrm{O}$ emission is sensitive to temperature changes in different land use types and ecosystems. K.A. Smith et al., (1998) indicated the order of $\mathrm{N}_{2} \mathrm{O}$ emissions from different land use types and ecosystems: grazed grassland $>$ grassland cut for conservation $>$ potatoes $>$ cereal crops and $\mathrm{N}_{2} \mathrm{O}$ emissions from agroecosystems were generally higher than those from temperate natural ecosystems. Their study also proved that the $Q_{10}$ value for a sandy loam was 1.6 but ranged up to 12 for a clay loam soil at high water-filled pore space. The high $Q_{10}$ values for $\mathrm{N}_{2} \mathrm{O}$ emission related to the condition in which denitrification was likely to be the dominant mechanism ${ }^{28)}$. The vegetable soil in this study was more sensitive to temperature change than the previous studies, whereas biochar treatments were less sensitive to temperature changes. The $Q_{10}$ values of $\mathrm{CO}_{2}$ at $5^{\circ} \mathrm{C}$ changes from $25^{\circ} \mathrm{C}$ to $30^{\circ} \mathrm{C}$ showed that $\mathrm{CO}_{2}$ emissions 
from biochar-added soil were more sensitive to temperature change than the CT. However, when the temperature changes from $25^{\circ} \mathrm{C}$ to $35^{\circ} \mathrm{C}, \mathrm{CO}_{2}$ emission from the soil with biochar application is less sensitive to temperature change than the CT. The $Q_{10}$ values in this study were lower than the previous study ${ }^{31)}$.

\section{CONCLUSIONS}

The first objective was to determine the effects of different coffee waste biochar materials on the reduction of $\mathrm{N}_{2} \mathrm{O}$ and $\mathrm{CO}_{2}$ emissions and our results showed that application of normal biochar caused more $\mathrm{CO}_{2}$ emission but less $\mathrm{N}_{2} \mathrm{O}$ emission compared to functional biochar application. In $\mathrm{N}_{2} \mathrm{O}$ and $\mathrm{CO}_{2}$ response to temperature, amendment with two types of coffee waste biochar reduced $\mathrm{N}_{2} \mathrm{O}$ and $\mathrm{CO}_{2}$ emissions at $35^{\circ} \mathrm{C}$ compared to no biochar amendment. There was little difference between treatments with respect to $\mathrm{N}_{2} \mathrm{O}$ and $\mathrm{CO}_{2}$ emissions but the key factor responsible for this reduction at $35^{\circ} \mathrm{C}$ is unknown. It might be related to the soil-biochar mixture's immobilization of available soil N. Our findings showed that when increasing temperature, a positive correlation between temperature and $\mathrm{N}_{2} \mathrm{O}$ and $\mathrm{CO}_{2}$ emissions in the non-biochar amendment and a negative correlation between temperature and $\mathrm{N}_{2} \mathrm{O}$ in the biochar treatments were observed. No correlation between $\mathrm{CO}_{2}$ production and temperature was seen in the biochar treatments with increasing temperature.

This study did not examine the mechanism of biochar application effects on $\mathrm{N}_{2} \mathrm{O}$ and $\mathrm{CO}_{2}$ emissions when increasing temperature. Further studies need to be conducted to clarify the simultaneous mechanism of functional and normal biochar addition to soil on $\mathrm{N}_{2} \mathrm{O}$ and $\mathrm{CO}_{2}$ emissions at a specific temperature.

\section{ACKNOWLEDGEMENTS}

We would like to thank Satoshi Hayashi and Riei Yokoyama at Nissoku Corporation, Okayama, Japan for providing coffee waste biochar. We also thank Takuya Fujimura for his assistance in soil analysis.

\section{REFERENCES}

1) Metz B., Davidson O. R., Bosch P. R., Dave R. \& Meyer L. A.: Climate Change 2007: Synthesis Report. Contribution of working groups I, II and III to the Fourth Assessment Report of the Intergovernmental Panel on Climate Change. 2007.

2) Smith P., Metz B. \& Davidson O. R.: Contribution of Working Group III to the Fourth Assessment Report of the Intergovernmental Panel on Climate Change. In: Climate Change Mitigation (eds B. Metz, O.R. Davidson, P.R. Bosch, R. Dave \& L.A. Meyer). Cambridge University Press, pp. 498-540, 2007.

3) Khai N. M., Ha P. Q. \& Öborn I.: Nutrient flows in small-scale peri-urban vegetable farming systems in Southeast Asia - A case study in Hanoi. Agriculture, Ecosystems \& Environment, Vol. 122, pp. 192-202, 2007.

4) Wang H. J., Huang B., Shi X. Z. et al.: Major nutrient balances in small-scale vegetable farming systems in peri-urban areas in China. Nutrient Cycling in Agroecosystems, Vol. 81, pp. 203-218, 2008.

5) Zhang M., Chen Z. Z., Li Q. L., Fan C. H. \& Xiong Z. Q.: Quantitative relationship between nitrous oxide emissions and nitrogen application rate for a typical intensive vegetable cropping system in Southeastern China. Clean Soil, Air, Water, Vol. 44 (12), pp. 1725-1732, 2016.

6) Xie T., Sadasivam B. Y., Reddy K. R., Wang C. \& Spokas K.: Review of the effects of biochar amendment on soil properties and carbon sequestration. Journal of Hazardous, Toxic, and Radioactive Waste, Vol. 20, pp. 1-14, 2016.

7) Cayuela M. L., van Zwieten L., Singh B. P., Jeffery S., Roig A. \& Sánchez-Monedero M. A.: Biochar's role in mitigating soil nitrous oxide emissions: A review and meta-analysis. Agriculture, Ecosystems \& Environment, Vol. 191, pp. 5-16, 2014.

8) Sánchez-García M., Roig A., Sánchez-Monedero M. A. \& Cayuela M. L.: Biochar increases soil $\mathrm{N}_{2} \mathrm{O}$ emissions produced by nitrification-mediated pathways. Frontiers in Environmental Science, Vol. 2, pp. 1-10, 2014.

9) Spokas K. A. \& Reicosky D. C.: Impacts of sixteen different biochars on soil greenhouse gas production. Annals of Environmental Science, Vol. 3, pp. 179-193, 2009.

10) Yoo G. \& Kang H.: Effects of biochar addition on greenhouse gas emissions and microbial responses in a short-term laboratory experiment. Journal of Environmental Quality, Vol. 41, pp. 1193-1202, 2012.

11) Zhang. H., Voroney R. P. \& Price G. W.: Effects of biochar amendments on soil microbial biomass and activity. Journal of Environmental Quality, Vol. 43, pp. 2104-2114, 2014.

12) Li B., Bi Z. \& Xiong Z.: Dynamic responses of nitrous oxide emission and nitrogen use efficiency to nitrogen and biochar amendment in an intensified vegetable field in southeastern China. GCB Bioenergy, Vol. 9, pp. 400-413, 2016.

13) García-Marco S., Ravella S. R., Chadwick D., Vallejo A., Gregory A. S. \& Cárdenas L. M.: Ranking factors affecting emissions of GHG from incubated agricultural soils. European Journal of Soil Science, Vol. 65, pp. 573-583, 2014.

14) Liang L. L., Grantz D. A. \& Jenerette G. D.: Multivariate regulation of soil $\mathrm{CO}_{2}$ and $\mathrm{N}_{2} \mathrm{O}$ pulse emissions from agricultural soils. Global Change Biology, Vol. 22, pp. 1286-1298, 2016.

15) Benoit M., Garnier J. \& Billen G.: Temperature dependence of nitrous oxide production of a luvisolic soil in batch experiments. Process Biochemistry, Vol. 50, pp. 79-85, 2015. 


\section{NITROUS OXIDE AND CARBON DIOXIDE EMISSIONS FROM AGRICULTURAL SOIL AMENDED WITH DIFFERENT TYPES OF BIOCHAR AT THREE TEMPERATURES}

16) Signor D., Cerri C. E. P. \& Conant R.: $\mathrm{N}_{2} \mathrm{O}$ emissions due to nitrogen fertilizer applications in two regions of sugarcane cultivation in Brazil. Environmental Research Letters, Vol. 8, pp. 1-9, 2013.

17) Yokoyama J. T, Hayashi S., Nakanishi M. \& J. T.: Nitrate nitrogen adsorption of the functional charcoal prepared from vegetable waste. Proceedings of International Symposium on EcoTopia Science 2007, pp. 161-165, 2007.

18) Shackley S., Sohi S., Ibarrola R. et al.: Biochar, tool for climate change mitigation and soil management. Geoengineering responses to climate change: selected entries from the Encyclopedia of Sustainability Science and Technology, pp. 73-140, Springer, New York, 2013.

19) Harter J., Krause H.-M., Schuettler S. et al.: Linking $\mathrm{N}_{2} \mathrm{O}$ emissions from biochar-amended soil to the structure and function of the N-cycling microbial community. International Society for Microbial Ecology, Vol. 8, pp. 660-674, 2014.

20) Cantarel A. A. M., Bloor J. M. G., Deltroy N. \& Soussana J. F.: Effects of climate change drivers on nitrous oxide fluxes in an upland temperate grassland. Ecosystems, Vol. 14, pp. 223-233, 2011.

21) Zhang J., Peng C., Zhu Q. et al.: Temperature sensitivity of soil carbon dioxide and nitrous oxide emissions in mountain forest and meadow ecosystems in China. Journal of Atmospheric Environment, Vol. 142, pp. 340-350, 2016.

22) Farquharson R.: Nitrification rates and associated nitrous oxide emissions from agricultural soils - a synopsis. Soil Research, Vol. 54, pp. 469-480, 2016.

23) Liu R., Hu H., Suter H. et al.: Nitrification is a primary driver of nitrous oxide production in laboratory microcosms from different land-use soils. Frontiers in Microbiology, Vol. 7, pp. 1-10, 2016.

24) Bremner J. M. \& Shaw K.: Denitrification in soil. II. Factors affecting denitrification. Journal of Agricultural Science, Vol. 51, pp. 40-52, 2009.

25) Hermann Bothe, Stuart Ferguson \& William E. N.: Biology of the Nitrogen Cycle: COST edition, Elsevier, The Netherlands, 2006.

26) Sun P., Zhuge Y., Zhang J. \& Cai Z.: Soil pH was the main controlling factor of the denitrification rates and $\mathrm{N}_{2} / \mathrm{N}_{2} \mathrm{O}$ emission ratios in forest and grassland soils along the Northeast China Transect (NECT). Soil Science and Plant Nutrition, Vol. 58, pp. 517-525, 2012.

27) Cayuela M. L., Sánchez-Monedero M. A., Roig A., Hanley K., Enders A. \& Lehmann J.: Biochar and denitrification in soils: when, how much and why does biochar reduce $\mathrm{N}_{2} \mathrm{O}$ emissions? Scientific Reports, Vol. 3, pp. 1-7, 2013.

28) Smith K. A., Thomson P. E., Clayton H., McTaggart I. P. \& Conen F.: Effects of temperature, water content and nitrogen fertilisation on emissions of nitrous oxide by soils. Atmospheric Environment, Vol. 32, pp. 3301-3309, 1998.

29) Bailey L. D.: Effects of temperature and root on denitrification in a soil. Canadian Journal of Soil Science, Vol. 56, pp. 79-87, 1976.

30) Keeney D. R., Fillery I. R. \& Marx G. P.: Effect of temperature on the gaseous nitrogen products of denitrification in a silt loam soil. Soil Science Society of America Journal, Vol. 43, pp. 1124-1128, 1979.

31) Siriporn Wiriyatangsakul, Amnat Chidthaisong, Sudarut Tripetchkul \& Limtong P.: Effects of moisture and temperature on respiration in tropical forest and agricultural soils. Kasetsart J. (Natural Science), Vol. 40, pp. 395-409, 2006.

(Received: April 20, 2017; Accepted: November 29, 2017) 